REFERENCES

Armstrong, M. D., Centerwall, W. R., Horner, F. A., Low, N. L., and Weil, W. B., jun. (1959). Chemical Pathology of the Nervous System. Pergamon Press, New York.

Low, N. L., and Bosma, J. F. (1957). Amer. J. clin. Nutr., 5, 543

Baird, H. W., III (1958). J. Pediat. 52, 715.

Berry, J. P., and Woolf, L. I. (1952). Nature (Lond.), 169, 202. Brimblecombe, F. S. W., Stoneman, M. E. R., and Maliphant, R. (1959). Lancet, 1, 609.

Centerwall, W. R. (1957a). J. Amer. med. Ass., 165, 392

- (1957b). Ibid., 165, 2219.

Felix, K., Leonhardi, G., and Glasenapp, I. von (1951). HoppeSeylers Z. physiol. Chem., 287, 141 .

Folling, A., and Syndes, S. (1958). Scand. J. clin. Lab. Invest., 10, 355 .

Horner, F. A., and Streamer, C. W. (1956). J. Amer. med. Ass., $161,1628$.

Hsia (1959), A.M.A. J. Dis. Child., 97; 345

Hsia, D. Y.-Y. (1957). Personal communication. Knox, W. E., Quinn, K. V., and Paine, R. S. (1958). Pediatrics, 21, 178.

Levine, S. Z., Dann, M., and Marples, E. (1943). J. clin. Invest., 22, 551 .

- Marples, E., and Gordon, H. H. (1939). Science, 90, 620.

- (1941). J. clin. Invest., 20, 199

Mackenzie, D. Y., and Woolf, L. I. (1959). Brit. med. J., 1, 90 Morris, J. E., Harpur, E. R., and Goldbloom, A. (1950). J. clin. Invest., 29, 325

Rogers, W. F., and Gardner, F. H. (1949). J. Lab. clin. Med., 34, 1491 .

Rupe, C. O., and Free, A. H. (1958). American Chemical Society, 134th meeting, Abstracts of Papers, p. 63C.

Woolf, L. I., and Edmunds, M. E. (1950). Biochem. J., 47, 630. Woolf, Griffiths, R., and Moncrieff, A. (1955). Brit. med. J., 1, 57. Childh.. 33. 31.

\section{ORAL TREATMENT OF PERNICIOUS} ANAEMIA WITH VITAMIN $B_{12}$ AND DESICCATED HOG DUODENAL EXTRACT

BY

E. K. BLACKBURN, M.D., F.R.F.P.S.

G. H. SPRAY, D.Phil.

H. T. SWAN, M.B., M.R.C.P., D.C.H.

\section{G. R. TUDHOPE, M.D., B.Sc., M.R.C.P., M.R.C.P.Ed. AND}

\section{G. M. WILSON, M.D., F.R.C.P.}

From the Department of Haematology, Royal Infirmary, Sheffield; the Nuffield Department of Clinical Mcdicine, Radcliffe Infirmary, Oxford; and the Department of

Pharmacology and Therapeutics, University of Sheffield

Oral administration of a substance with intrinsic factor activity is a rational approach to the treatment of pernicious anaemia. However, treatment by adequate parenteral vitamin $B_{12}$ is so consistently effective in maintaining a normal state of the blood and bone marrow, and in safeguarding against the development of neurological complications, that any other form of therapy must be shown to be as effective before it can supplant injections of vitamin $B_{12}$ in the routine management of the disease. Oral therapy has an obvious attraction, and Wilkinson (1949) has shown that excellent results may be obtained by the use of a relatively crude preparation of desiccated hog's stomach. In recent years preparations have been used in the treatment of pernicious anaemia containing, in tablet form, a small amount (5-15 $\mu \mathrm{g}$.) of vitamin $B_{12}$ and an extract of desiccated hog duodenal or pyloric mucosa. Evidence has been accumulating that this form of therapy usually results in a good initial response, but with continued treatment haematological remission and normal levels of vitamin $B_{12}$ in the serum are not maintained (Bastrup-Madsen, 1957 ; Kristensen et al., 1957 ; Lowenstein et al., 1957 ; Killander, 1958). It has been shown that many patients treated with such oral preparations ultimately have reduced intestinal absorption of vitamin $B_{12}$ when hog pyloric mucosa is supplied as intrinsic factor (Lowenstein et al., 1957; Schwartz et al., 1957 ; Stokes and Pitney, 1958). This leads ultimately to deficiency of vitamin $B_{12}$ and clinical relapse.

The present report describes the results of treatment of pernicious anaemia patients with "biopar" tablets over a period of five years, and is an extension of a previous report on treatment with biopar for one year (Blackburn et al., 1955). The changes in the peripheral blood, the bone marrow, and the levels of vitamin $B_{12}$ in the serum have been followed during this period of treatment. In addition, tests were made for skin sensitivity to hog intrinsic factor prepared by the same method as used in biopar tablets.

\section{Patients Studied and Details of Treatment}

The results of oral treatment with tablets containing crystalline vitamin $B_{12}$ and a desiccated extract of hog duodenal mucosa (biopar and biopar forte) have been studied in 22 patients with Addisonian pernicious anaemia. In all cases the diagnostic criteria included megalocytic anaemia, megaloblastic erythropoiesis in the bone marrow, histamine-fast gastric achlorhydria, and the absence of evidence of steatorrhoea or other recognized cause of megaloblastic anaemia. Each tablet of biopar contained $6 \mu \mathrm{g}$. of vitamin $B_{12}$ and 30 mg. of the intrinsic factor preparation; each tablet of biopar forte contained $15 \mu \mathrm{g}$. of vitamin $B_{12}$ and $35 \mathrm{mg}$. of the intrinsic factor preparation.

Thirteen patients (Cases 1-13) who had previously been treated with parenteral vitamin $B_{12}$, and in whom steady and normal levels of haemoglobin and red-cell count had been maintained during at least one year, were transferred to treatment with biopar in November, 1953. From then until June, 1955, these patients received one tablet of biopar daily. The dose was then increased to two tablets daily until October, 1956. In 1956 the production of biopar tablets was stopped, and they were replaced by biopar forte. From October, 1956, until March, 1959, treatment was given with biopar forte, two tablets daily.

Nine patients with previously untreated pernicious anaemia who had shown a satisfactory initial response to oral treatment were included in the study. Four of these patients (Cases 14-17) were given initially five tablets of biopar daily. This was continued for two to nine months, until June, 1955, when they were transferred to the above scheme of dosage. Five patients (Cases 18-22) received biopar forte, five tablets daily for six months, and then continued treatment with two tablets daily.

The results during the first year of treatment with biopar in 10 of these patients have already been published (Blackburn et al., 1955). Of the 22 patients included in the present study, five did not complete the trial for reasons detailed below.

\section{Methods of Investigation}

In all cases determinations of haemoglobin level (M.R.C. grey wedge photometer ; oxyhaemoglobin- 
$100 \%=14.8$ g. $/ 100 \mathrm{ml}$.) and standard red-cell count were made every four to eight weeks.

Biopsy of iliac bone marrow was performed in 13 patients after treatment with biopar for $3 \frac{1}{2}$ years, and in nine patients further marrow examination was made at the end of five years of oral therapy.

The concentration of vitamin $B_{12}$ in the serum was estimated after treatment with biopar for $2 \frac{1}{2}, 3 \frac{1}{2}$, and 5 years. In five patients this estimation was carried out before starting therapy and again after treatment with biopar for six to 13 months. The amount of vitamin $\mathbf{B}_{12}$ in samples of serum was estimated by microbiological assay, using Lactobacillus leichmannii as the test organism (Spray, 1955).

Skin-testing was carried out with an extract of hog pyloric mucosa, as contained in biopar tablets. In each test, $0.02 \mathrm{ml}$. of a $1 / 100$ dilution of the extract in normal saline was injected intradermally on the front of the right forearm. A control injection of $0.02 \mathrm{ml}$. of normal saline was also given on the left forearm.

\section{Results}

The levels of haemoglobin and red-cell count during the first year of treatment with biopar in 12 patients formed the subject of a previous publication (Blackburn et al., 1955). Of these 12 patients, two were not included in the subsequent study. One died of pneumonia soon after the end of the first year; peripheral blood examination had been within normal limits a few weeks before death. The other patient developed persistent paraesthesiae in the hands at the end of the first year, without objective signs of neurological abnormality and without abnormality of the blood. Nevertheless, treatment with biopar was stopped and injections of vitamin $B_{12}$ were recommenced. There was little symptomatic change after parenteral vitamin $B_{12}$ therapy, and it now seems unlikely that any neurological changes due to vitamin- $B_{12}$ deficiency had been present. Two other patients died during the subsequent study: one (Case 13) died of coronary thrombosis after three years, and the other (Case 6) died of carcinoma of the prostate after four years of treatment with biopar. In each of these cases the last haemoglobin estimation, redcell count, and blood film, made within a few weeks of death, were normal.

Haematological relapse occurred in three patients out of a total of 17 after treatment with biopar for $2 \frac{1}{2}$ to 5 years. These patients were believed to be reliable, and they stated that they had taken the prescribed tablets regularly.

Case 1.-This patient, who had previously received parenteral therapy with liver extract and later vitamin $\mathbf{B}_{12}$ for a total of seven years, showed a persistent fall in redcell count to about $3,600,000 / \mathrm{c} . \mathrm{mm}$., associated with macrocytosis in the peripheral blood film after treatment with biopar for five years. The level of vitamin $\mathbf{B}_{12}$ in the serum at this time was $65 \mu \mu \mathrm{g}$. $/ \mathrm{ml}$. and the bone marrow showed the typical appearances of vitamin- $B_{12}$ deficiency in the red-cell and white-cell precursors. There was a prompt return of the blood to normal after the resumption of parenteral vitamin- $B_{12}$ therapy.

Case 3.-Previous treatment with liver extract and later vitamin $\mathbf{B}_{12}$ had been given for a total of six years. After treatment with biopar for $3 \frac{1}{2}$ years the red-cell count, which had previously been maintained above 4,500,000/ c.mm., showed a persistent fall, reaching $2,500,000 / \mathrm{c} . \mathrm{mm}$., and the peripheral blood film contained many macrocytes. The bone marrow showed megaloblastic erythropoiesis. The concentration of vitamin $B_{12}$ in the serum at this time was $30 \mu \mu \mathrm{g} . / \mathrm{ml}$. Parenteral therapy with vitamin $\mathbf{B}_{12}$ was followed by an increase in the red-cell count to $5,300,000 /$ c.mm. in one month.

Case 14.-This patient, with previously untreated pernicious anaemia, had initially shown an adequate haematological response to biopar. However, after treatment with biopar for 21 months the level of vitamin $B_{12}$ in the serum was $56 \mu \mu \mathrm{g} . / \mathrm{ml}$., and seven months later it was $10 \mu \mu \mathrm{g} . / \mathrm{ml}$. At this time the red-cell count began to fall and reached $2,900,000 / \mathrm{c} . \mathrm{mm}$., the bone marrow showing megaloblastic erythropoiesis. After parenteral therapy with vitamin $\mathbf{B}_{12}$ the red-cell count returned to normal.

Two other patients (Cases 2 and 4) showed a fall in haemoglobin level and in red-cell count while on biopar therapy. In both cases the appearances of the peripheral blood film suggested concomitant iron deficiency, and the blood returned to normal when oral treatment with iron was given in addition to biopar.

In the remaining 12 patients in this series the levels of haemoglobin and red-cell count have remained within the normal range during the period of biopar treatment. Statistical analysis of all the red-cell counts made during the entire period of treatment in these cases has not revealed any significant trend. In no case did neurological signs develop during biopar treatment.

Examination of the bone marrow was made after treatment with biopar for $2 \frac{1}{2}$ to $3 \frac{1}{2}$ years in 13 patients (Table I); typical megaloblasts were present in two

TABLE I.-Levels of Vitamin $B_{12}$ in Serum and the Appearance of Bone Marrow During Treatment with Biopar in 17 Patients With Pernicious Anaemia

\begin{tabular}{|c|c|c|c|c|c|c|}
\hline \multirow{2}{*}{$\begin{array}{l}\text { Case } \\
\text { No. }\end{array}$} & \multirow{2}{*}{$\begin{array}{c}\text { Age } \\
\text { and Sex }\end{array}$} & \multicolumn{3}{|c|}{$\begin{array}{l}\text { Serum Level of Vitamin } B_{12} \\
(\mu \mu \mathrm{g} / / \text { ml.) after Treatment } \\
\text { with Biopar for }\end{array}$} & \multicolumn{2}{|c|}{$\begin{array}{l}\text { Evidence of Vitamin- } \\
\text { B }_{12} \text { Deficiency in } \\
\text { Bono Marrow }\end{array}$} \\
\hline & & $2 \frac{1}{2}$ Yrs. & $3 \frac{1}{2}$ Yrs. & 5 Yrs. & $3 \frac{1}{2}$ Yrs. & 5 Yrs. \\
\hline $\begin{array}{r}1 \\
2 \\
3 \\
4 \\
5 \\
6 \\
7 \\
8 \\
9 \\
10 \\
11 \\
12 \\
13 \\
14\end{array}$ & $\begin{array}{ll}69 & \mathrm{~F} \\
74 & \mathrm{~F} \\
78 & \mathrm{M} \\
73 & \mathrm{~F} \\
75 & \mathrm{~F} \\
82 & \mathrm{M} \\
82 & \mathrm{M} \\
70 & \mathrm{~F} \\
50 & \mathrm{~F} \\
89 & \mathrm{~F} \\
52 & \mathrm{M} \\
53 & \mathrm{~F} \\
65 & \mathrm{M} \\
78 & \mathrm{~F}\end{array}$ & $\begin{array}{l}160 \\
280 \\
140 \\
270 \\
190 \\
180 \\
78 \\
210 \\
220 \\
110 \\
590 \\
110 \\
10\end{array}$ & $\begin{array}{r}35 \\
240 \\
76 \\
90 \\
110 \\
120 \\
19 \\
75 \\
120 \\
84 \\
32 \\
430 \\
=\end{array}$ & $\begin{array}{c}65 \\
250 \\
30(4 \mathrm{yr} .) \\
65 \\
100 \\
- \\
35 \\
140 \\
170 \\
72 \\
40 \\
290 \\
= \\
=\end{array}$ & $\begin{array}{c}+ \\
0 \\
++ \\
+ \\
0 \\
+ \\
+ \\
+ \\
0 \\
+ \\
0 \\
- \\
++\end{array}$ & $\begin{array}{c}++ \\
\pm \\
++ \\
= \\
++ \\
\overline{0} \\
\overline{0} \\
= \\
=\end{array}$ \\
\hline $\begin{array}{l}15 \\
16 \\
17\end{array}$ & $\begin{array}{ll}58 & \mathrm{~F} \\
42 & \mathrm{~F} \\
41 & \mathrm{M}\end{array}$ & $\begin{array}{l}130 \\
220 \\
460\end{array}$ & $\frac{69}{340}$ & $\begin{array}{l}100 \\
170 \\
830\end{array}$ & $\frac{+}{0}$ & $\begin{array}{r}0 \\
+ \\
+ \\
0\end{array}$ \\
\hline
\end{tabular}

The results of marrow biopsy are classified in three categories: no evidence of vitamin- $\mathrm{B}_{12}$ deficiency, $(0)$; slight abnormalities consistent with but not
diagnostic of vitamin- $\mathrm{B}_{12}$ deficiency, $(+)$; evidence of vitamin- $\mathrm{B}_{12}$ deficiency, $(++)$.

(Cases 3 and 14), who therefore were treated subsequently with parenteral vitamin $B_{12}$. In six there were minor abnormalities suggestive but not diagnostic of vitamin- $\mathrm{B}_{12}$ deficiency, and in the remaining five the marrow appeared normal. Bone-marrow examination after treatment with biopar for five years showed megaloblasts typical of vitamin- $B_{12}$ deficiency in four of nine cases. Thus within five years megaloblasts were present in at least 6 out of 17 cases.

The results of estimations of vitamin $B_{12}$ in the serum are shown in Table I. By the method used the normal range is $150-1,000 \mu \mu \mathrm{g} . / \mathrm{ml}$. (Spray and Witts, 1958). After treatment with biopar for $2 \frac{1}{2}$ years the level of vitmain $B_{12}$ in the serum was less than $150 \mu \mu \mathrm{g} . / \mathrm{ml}$. in 6 out of 16 cases, and after treatment for $3 \frac{1}{2}$ years the level was abnormally low in 11 cases. It is noteworthy that, in the patients in whom the concentration of vitmain $B_{12}$ in the serum was normal after treatment 
with biopar for $3 \frac{1}{2}$ years, the level was still within the normal range after treatment for five years.

In the nine cases (Nos. 14-22) of hitherto untreated pernicious anaemia, treatment with biopar resulted in a satisfactory initial response. The increase in red cells in 14 days was very similar to the "average response" to potent liver extract (Della Vida and Dyke, 1942),

Table II.-Levels of Vitamin $B_{12}$ in Serum in Five Patients With Pernicious Anaemia Before Starting Treatment, and After Treatment with Biopar Tablets for 6 to 13 Months

\begin{tabular}{|c|c|c|c|c|}
\hline \multirow{2}{*}{$\begin{array}{l}\text { Case } \\
\text { No. }\end{array}$} & \multirow{2}{*}{$\begin{array}{c}\text { Age } \\
\text { and Sex }\end{array}$} & \multicolumn{2}{|c|}{$\begin{array}{c}\text { Serum Level of Vitamin } B_{12} \\
(\mu \mu \mathrm{g} . / \mathrm{ml} .)\end{array}$} & \multirow{2}{*}{$\begin{array}{c}\text { Duration } \\
\text { of } \\
\text { Treatment } \\
\text { with } \\
\text { Biopar } \\
\text { (Months) }\end{array}$} \\
\hline & & $\begin{array}{c}\text { Before } \\
\text { Treatment }\end{array}$ & $\begin{array}{c}\text { After } \\
\text { Treatment } \\
\text { with Biopar }\end{array}$ & \\
\hline $\begin{array}{l}18 \\
19 \\
20 \\
21 \\
22\end{array}$ & $\begin{array}{ll}\mathbf{6 0} & \mathrm{F} \\
\mathbf{6 3} & \mathrm{F} \\
76 & \mathrm{~F} \\
70 & \mathrm{~F} \\
\mathbf{6 2} & \mathrm{F}\end{array}$ & $\begin{array}{l}20 \\
22 \\
25 \\
52 \\
30\end{array}$ & $\begin{array}{r}200 \\
250 \\
88 \\
52 \\
92\end{array}$ & $\begin{array}{r}13 \\
9 \\
6 \\
8 \\
9\end{array}$ \\
\hline
\end{tabular}

except in one case, in which there was evidence of concomitant iron deficiency; a reticulocyte response of $32 \%$ (dry method) followed the start of biopar therapy, but the increase in red cells was at first slow. When iron by mouth was added the red-cell count rapidly increased to normal. However, when the level of vitamin $B_{12}$ in the serum was estimated in five of these patients after treatment with biopar for 6 to 13 months, it was within the normal range in only two (Table II).

Skin tests by intradermal injection of a $1 / 100$ dilution of an extract of hog pyloric mucosa were carried out in 13 patients after treatment with biopar for four to five years. For comparison, skin tests were performed, using the same technique and preparation of hog pyloric mucosa, in 16 patients with pernicious anaemia who had been treated for 2 to 20 years with liver or vitamin-B injections, and who had never received biopar tablets or other oral preparation for the treatment of pernicious anaemia. A slight positive reaction was observed in three of the biopar patients; in two of these the level of vitamin $B_{12}$ in the serum was abnormally low (Cases 11 and 21), and in one it was normal (Case 12). The reaction consisted of an area of erythema about $1 \mathrm{~cm}$. in diameter, observed 15 to 30 minutes after injection, with no reaction to the control injection. In no patient was there any weal formation or pruritus. A similar slight positive reaction was observed in 2 of the 16 patients with pernicious anaemia who had never received biopar.

\section{Discussion}

The results of this study show that neither biopar nor biopar forte is reliable in the treatment of pernicious anaemia. In the group of patients who had been well maintained previously by parenteral vitamin $B_{12}$ the levels of vitamin $B_{12}$ in the serum became abnormally low in 11 out of 14 , after treatment with biopar for $3 \frac{1}{2}$ years. In two of these patients there was a reduction in red-cell count with clinical relapse after $3 \frac{1}{2}$ to 5 years of biopar therapy. The patients with previously untreated pernicious anaemia showed a satisfactory clinical and haematological response at first to biopar treatment, but in several cases the level of vitamin $B_{12}$ in the serum was abnormally low after six to nine months, and in one patient there was haematological relapse after $2 \frac{1}{2}$ years. One case has previously been reported in which there was a failure of initial response to biopar but subsequent good response to parenteral vitamin $B_{12}$ (Blackburn et al., 1955). These results with biopar are very similar to the published results with other oral preparations containing a small amount of vitamin $B_{12}$ along with an extract of hog pyloric mucosa"bifacton" (Mollin and Ross, 1954; Killander, 1958), "bendogen" (Berlin et al., 1958), and "cycoplex" (Kristensen et al., 1957 ; Lowenstein et al., 1957). As with these other oral preparations, increasing the dose of biopar did not prevent relapse.

The haemoglobin concentration and red-cell count remained normal for up to at least two years after the level of vitamin $B_{12}$ in the serum had been found to be abnormally low; a similar time lag in haematological relapse was reported by Killander (1958), and it is clear that satisfactory levels of haemoglobin and red-cell count over a period of years in a patient with pernicious anaemia is not proof that the treatment given is adequate in preventing vitamin- $\mathrm{B}_{12}$ deficiency.

The failure of oral preparations containing vitamin $\mathrm{B}_{12}$ and hog pyloric mucosa to maintain remission in pernicious anaemia after an initial good response appears to result from a late development of a block in the intestinal absorption of vitamin $B_{12}$. When refractoriness to these oral preparations develops, labelled vitamin $\mathbf{B}_{12}$ is not absorbed when given orally along with hog pyloric mucosa, but is well absorbed when given with normal human gastric juice (Killander, 1957 ; Lowenstein et al., 1957 ; Schwartz et al., 1957 ; Berlin et al., 1958; and Stokes and Pitney, 1958). Taylor and Morton (1958) have produced specific rabbit antisera which can neutralize human or pig intrinsic factor activity, and Schwartz (1958) has shown that the serum of some patients treated with oral preparations of vitamin $B_{12}$ and hog pyloric mucosa has the property of inhibiting intrinsic factor. This cannot explain all the observed phenomena in pernicious anaemia treated by oral preparations, as the inhibitory activity was observed against human intrinsic factor as well as hog pyloric mucosa.

The skin tests performed with the extract of hog duodenal mucosa failed to demonstrate any relationship between skin sensitivity to the extract and relapse of pernicious anaemia during treatment with biopar. Although two patients who had low levels of vitamin $B_{12}$ in the serum after treatment with biopar showed a slight positive reaction, a similar response was obtained in one biopar patient who had a normal level of vitamin $B_{12}$ in the serum and in two patients with pernicious anaemia who had never received biopar.

Small daily oral doses of vitamin $B_{12}$ without added intrinsic factor may produce haematological response in some patients with pernicious anaemia (Estren and Wasserman, 1956 ; Chalmers and Shinton, 1958), and it is possible that the initial response to biopar reported above in previously untreated cases of pernicious anaemia may have resulted entirely from the vitamin-B $B_{12}$ content of the tablets. The patients with previously untreated pernicious anaemia in the series now reported received, in the biopar tablets, 30-75 $\mu \mathrm{g}$. of vitamin $B_{12}$ daily for up to nine months. Chalmers and Shinton (1958) have shown that $50 \mu \mathrm{g}$. of vitamin $B_{12}$ daily, given orally, produced haematological response, but did not maintain normal levels of vitamin $B_{12}$ in the serum, whereas $100 \mu \mathrm{g}$. of vitamin $B_{12}$ daily by mouth resulted in normal levels of vitamin $B_{12}$ in the serum.

\section{Summary}

Oral treatment of pernicious anaemia with " biopar," a preparation containing vitamin $B_{12}$ and an extract of 
hog duodenal mucosa, has been studied in 22 patients. Thirteen patients who had previously been treated satisfactorily with parenteral vitamin $B_{12}$ for at least one year, received biopar therapy for up to five years. After $3 \frac{1}{2}$ years the level of vitamin $B_{12}$ in the serum was abnormally low in most patients, and haematological relapse occurred in two patients after four to five years.

Nine patients with previously untreated pernicious anaemia showed a satisfactory initial response to biopar therapy, but one relapsed after $2 \frac{1}{2}$ years and in four others the vitamin $B_{12}$ in the serum did not reach a satisfactory level. The level of vitamin $B_{12}$ in the serum reached the normal range in the remaining four, in two of whom normal values were still found after treatment for five years.

Skin tests performed with an extract of hog duodenal mucosa did not show any relationship between skin sensitivity to the extract and refractoriness to biopar treatment.

The results of the investigation show that this oral treatment is not reliable for maintenance of patients with pernicious anaemia.

We thank Dr. G. H. Jowett and staff of the department of statistics, University of Sheffield, for statistical help. We are grateful to the technical staff of the haematology department, Royal Infirmary, Sheffield, for their assistance ; to Mrs. Beryl Godfrey, Mrs. Elizabeth Ross, B.Sc., and Miss Janet Nelson for their help in carrying out the microbiological assays; and to Mr. D. Purdie and his colleagues of the Armour Laboratories for the extract of hog duodenal mucosa used in skin-testing and for their co-operation throughout.

\section{REFERENCES}

Bastrup-Madsen, P. (1957). Acta med. scand., 159, 323.

Berlin, R., Berlin, H., Brante, G., and Sjöberg, S-G. (1958). Ibid., 161, 143

Blackburn, E. K., Cohen, H., and Wilson, G. M. (1955). Brit. med. J., 2,461 .

Chalmers, J. N. M., and Shinton, N. K. (1958). Lancet, 2 , 1298 .

Della Vida, B. L., and Dyke, S. C. (1942). Ibid., 2, 275.

Estren, S., and Wasserman, L. R. (1956). Proc. Soc. exp. Biol. (N.Y.), 91, 499 .

Killander, A. (1957). Lancet, 1, 1041.

(1958). Acta med. scand., 160, 339.

Kristensen, H. P. Ø., Lund, J., Ohlsen, A. S., and Pedersen, J. (1957). Lancet, 1, 1266.

Lowenstein, L., Brunton, L., Shapiro, L., De Leeuw, N., and Dufresne, M. (1957). Canad. med. Ass. J., 77, 923.

Mollin, D. L., and Ross, G. I. M. (1954). Proc. roy. Soc. Med., 47, 428.

Schwartz, M. (1958). Lancet, 2, 61 .

Lous, P., and Meulengracht, E. (1957). Ibid., 1, 751

Spray, G. H. (1955). Clin. Sci., 14, 661.

and Witts, L. J. (1958). Brit. med. J., 1, 295

Stokes, J. B., and Pitney, W. R. (1958). Ibid., 1, 322

Taylor, K. B., and Morton, J. A. (1958). Lancet, 1, 29.

Wilkinson, J. F. (1949). Ibid., 1, 249.

The polio vaccination campaign among young people is being intensified in two of the L.C.C.'s health divisions in north London. Dr. J. A. ScorT, the L.C.C.'s Medical Officer of Health, has written to nearly 10,000 firms, coffee bars, dance halls, hairdressers, gramophone record shops, and others in Finsbury, Hackney, Holborn, Islington, Shoreditch, and Stoke Newingtor to ask for their help. In Finsbury, Holborn, and Islington the council will use a mobile clinic to take "the jab to the job," parking in or near the factories and offices where the young people work. Up to September this year there have been 84 confirmed cases of polio in these six north London boroughs, six of them fatal. But Dr. Scott points out that quite three-quarters of young Londoners between the ages of 15 and 26 have not yet sought protection: this despite the fact that the chances of being attacked by polio are about five times greater for the unvaccinated than for the vaccinated.

\section{PLACENTAL IMPLANTATION FOR PERIPHERAL VASCULAR DISEASE}

\author{
BY
}

C. W. A. FALCONER, F.R.C.S.

Surgeon-in-Charge, General Surgical Unit, Western General Hospital, Edinburgh

AND

\section{A. A. GUNN, F.R.C.S.}

Registrar, Western General Hospital, Edinburgh

Since Filatov (1935) reported the use of various tissue implants as an aid in corneal grafting, numerous papers have been published from the continent of Europe advocating placental tissue or placental extract in the treatment of many diseases. Sneep (1955) from Holland, and Piccoli (1954) and Cordaro (1957) from Italy, have recommended this therapy for advancing the healing of wounds and ulcers, while in the German literature several reports have appeared on the use of placental extract in the disturbances of the climacteric (Branger and Krattiger-Müller, 1957). The extract has also been used in skin wounds by Bromilski (1956), of Poland, and in intestinal fistula by Junod (1954), of France. In this country Troensegaard-Hansen (1956) has used amnion both as an implant and as a surface application for ulcers.

In 1956 D. Le Grand (personal communication) stated that implantation of the cotyledon surface of the placenta gave spectacular results in persistent intermittent claudication, and the present paper is a favourable preliminary report of a clinical trial of this method of treatment.

\section{Method}

Selection of Patients.-Every patient reporting to the clinic on account of severe intermittent claudication was admitted for investigation and included in the first part of this trial. Later, the method was attempted on an out-patient basis. These patients had previously had Buerger's exercises, and in many cases had received vasodilator drugs. A few had had a previous sympathectomy. Each patient was warned that two implants might be required, so that a control series could be arranged. If the control method of treatment failed, the patient received an implant of placenta.

Assessment of the Patients.-A full history and medical examination revealed the general state of the patient. Examination of the cardiovascular system was supplemented in most cases by an electrocardiogram and ophthalmoscopy. The peripheral circulation was assessed by inspection of the skin, palpation of the pulses, estimation of venous filling time, and exercise tolerance. The actual lesion was identified by arteriography, which also gave an indication of the collateral circulation and general state of the vessels. The capacity of the arteries to dilate was assessed by a reflex heating test and the blood flow in the limbs by oscillometry. This assessment enabled the patient to be placed in one of three groups suitable for: (1) conservative treatment, (2) sympathectomy, or (3) arterial graft. Patients in all three groups received placental implants as the first method of treatment.

Preparation of Placenta.-A placenta was delivered straight from the maternity unit in a sterile container. The blood group of mother and placenta was 